\title{
Quality characteristics and microbiological safety evaluation of oils extracted from gamma irradiated almond (Prunus dulcis Mill.) seeds
}

\author{
By I.A. Bhatti ${ }^{1, *}$, M. Iqbal' ${ }^{1}$, F. Anwar ${ }^{2, *}$, S.A. Shahid ${ }^{3}$ and M. Shahid ${ }^{1}$ \\ ${ }^{1}$ Department of Chemistry and Biochemistry, University of Agriculture, Faisalabad-38040, Pakistan \\ ${ }^{2}$ Department of Chemistry, University of Sargodha, Sargodha-40100, Pakistan \\ ${ }^{3}$ Department of Physics, University of Agriculture, Faisalabad-38040, Pakistan \\ *Corresponding authors: fqanwar@yahoo.com, ljazchem@yahoo.com
}

\section{RESUMEN}

Calidad y seguridad microbiológica de aceites extraídos de semillas de almendras (Prunus dulcis Mill.) sometidas a radiación gamma

Se ha evaluado las caracteristicas fisico-químicas y la descontaminación microbiana de aceites extraídos de semillas de almendras (variedades Misión y Price) gamma-irradiadas a dosis absorbidas de 2-10 kGy. La radiación gamma no ejerce ningún efecto considerable en la composición próximal de las semillas. Las características fisico-químicas tales como la densidad y el índice de refracción de los aceites, extraídos a partir de semillas gamma-irradiadas, permanecieron casi sin afectar; el índice de yodo disminuye mientras que el valor de saponificación, la materia insaponificable y los ácidos grasos libres aumentan. El estado oxidativo y el contenido de tocoferoles de los aceites de almendra se vieron afectados negativamente, mientras que el perfil de ácidos grasos se modifica ligeramente debido al estrés de la radiación. Curiosamente, los efectos sobre los atributos de calidad del aceite fueron más pronunciados a dosis de radiación más altas (> 6 kGy). Además, la contaminación microbiana se eliminó por completo en los aceites irradiados a una dosis absorbida de 6,0 kGy. Se puede concluir a partir de los presentes hallazgos que la radiación tiene un efecto positivo o negativo considerable en algunos atributos de la aceite de almendras. Por lo tanto, se debe aplicar una magnitud apropiada de radiación gamma para el tratamiento de semillas de almendra con el fin de retener los máximos beneficios nutritivos.

PALABRAS CLAVE: Ácidos grasos - Composición proximal - Descontaminación microbiana - Dosis absorbida - Estabilidad oxidativa - Radiación gamma - Tocoferoles.

\section{SUMMARY}

Quality characteristics and microbiological safety evaluation of oils extracted from gamma irradiated almond (Prunus dulcis Mill.) seeds

The physicochemical attributes and microbial decontamination of oils extracted from gamma-irradiated almond (Mission and Price varieties) seeds, to the absorbed doses of 2-10 kGy, have been evaluated. Gamma irradiation exerted no considerable effect on the proximate seed composition. The physicochemical properties such as density and refractive index of the oils, extracted from gammairradieted seeds, were almost unaffected; the iodine value decreased while saponification value, unsaponifiable matter and free fatty acids increased. The oxidative status and tocopherol content of almond oils were negatively affected while the fatty acid profile slightly changed due to irradiation stress. Interestingly, these effects on the oil quality attributes were more pronounced at higher irradiation doses (> $6 \mathrm{kGy}$ ). Besides, microbial contamination was completely eliminated in the oils irradiated to an absorbed dose of $6.0 \mathrm{kGy}$. It could be concluded from the present findings that irradiation has a considerably positive or negative effect on some attributes of the almond oil. Therefore, an appropriate magnitude of gamma irradiation should be exercised to treat almond seeds in order to retain maximum nutritive benefits.

KEY-WORDS: Absorbed doses - Fatty acids - Gamma irradiation - Microbial decontamination - Oxidative stability Proximate composition- Tocopherols.

\section{INTRODUCTION}

It is well known that vegetable oils undergo oxidative deterioration during processing and storage resulting in the formation of hydroperoxides, aldehydes, ketones, and carboxylic acids which decrease the nutritive and organoleptic value of the products (Richardsa et al., 2005; Bhatti et al., 2010). Oxidation not only causes rancidity in oils and lowers their nutritional value; but the the oxidation products formed exhibit harmful effects on the health of consumers (Muik et al., 2005; Azim et al., 2009; Barros et al., 2011; Rohman et al., 2011).

Irradiation treatment can protect food commodities from oxidation, insects infestation and microbial contamination during storage and processing (Yusof et al., 2007; Alighourchi et al., 2008; Thomas et al., 2008; Braghini et al., 2009). Development of this preservation technique is based on the consideration that high energy irradiation might affect minutely the nutritive value of stored food. However, a study of the relationship between radiation absorbed doses and possible changes in the composition of food stuffs must be carried out in order to comprehensively assess the acceptability of irradiated processed foods (Azim et al., 2009).

Exposing foods to ionizing radiation is similar to a heat treatment, either thermal or microwave, that generates minute and mostly undetectable changes in the chemical composition of food due to its selectivity and high efficiency with which it is 
transferred to the orbiting electrons in the atoms constituting food molecules and consequently produce free radicals. The free electrons are rapidly trapped by surrounding atom-forming anions. Most of the absorbed radiant energy is used to generate free radicals and to induce chemical reactions between radicals or between radicals and other molecules. Only a fraction of the absorbed energy is converted into heat, therefore, it is similar to a cold pasteurization technique (Siddhuraju et al., 2002). According to Graham et al., (2002) water is the predominant molecule in all living systems and is the principal primary reactant during radiorization. The free radicals formed in water radiolysis have the ability to recombine with the newly formed radical cations and react with other components in the food matrix to form secondary changes and thus stabilize organic compounds.

The application of gamma irradiation for food preservation has emerged as an effective tool for imparting longer shelf-life without inducing radioactive contamination (da Trindade et al., 2009; Ehlermann, 2009; Song et al., 2009; Jalili et al., 2010). Worldwide, a number of studies have reported that gamma- irradiated food items such as peanut, sunflower, herbs, almond oil (Oleum amygdalae), raw almond, olive oil, fresh meat, pecan nuts, cumin, Nigella sativa and pine nuts showed better physico-chemical status as well as biological characteristics verses non-irradiated foods (Lalas et al., 2007; Evren and Gulden, 2008; Mexis and Kontominas, 2009; Ahmad, 2010; Prakash et al., 2010).

Almond (Prunus dulcis Mill.), a member of the Rosaceae family, is cultivated globally, with about $28 \%$ of its worldwide production derived from the Mediterranean region (Chen et al., 2005; Wijeratne et al., 2006). Due to its high nutritional value, the almond is incorporated as an important ingredient in various confectionery products. Regular intake of almonds has been known to reduce cholesterol levels and lipoprotein profiles significantly which might be linked to its high-oleic lipids (Martins et al., 2003; Moure et al., 2007; Cordeiro and Monteiro, 2001). Apart from its nutritive value, the almond is reported to contain a wide variety of phenolics and flavonoids which posses interesting biological effects such as sedative, anti-inflammatory, anti-hyperlipidemic, anti-tumour and antioxidant activities (Chen et al., 2005; Milbury et al., 2006; Esfahlan et al., 2010).

Until now there have been no previous studies reported on irradiated almond seeds. As gamma irradiation is investigated to affect the physicochemical characteristics and nutritive quality of several foods; this prompts the need to evaluate the effect of such a treatment on the quality characteristics of almond oil. Besides, the oil extracted from the almond kernel, due to its considerably higher moisture content, is more receptive to microbial contamination and rancidity during storage, therefore, it would be worthwhile to improve its shelflife by using an irradiation process. In this regard, the present research was undertaken to investigate the physico-chemical and biological characteristics of oils extracted from two locally available varieties of gamma irradiated almond seeds.

\section{MATERIALS AND METHODS}

\subsection{Chemicals and reagents}

All the reagents used were of HPLC and analytical grade obtained from Sigma-Aldrich (Buches, Switzerland). Tocopherol standards, DL$\alpha$-tocopherol, (+) $\delta$-tocopherol, (+) $\gamma$-tocopherol and fatty acid methyl ester (FAMEs) were purchased from Sigma Chemicals Co (St. Louis, MO, USA).

\subsection{Sample collection and gamma irradiation}

Two varieties of almond, namely Mission and Price, were obtained from the local dry fruit market and further authenticated by the Department of Botany, University of Agriculture, Faisalabad, Pakistan. The samples were packed in polyethylene bags and then exposed to the gamma-radiation for the doses of 2, 4, 6, 8 and 10 KGy using Cs-137 gamma radiation source at the Nuclear Institute of Agriculture and Biology (NIAB), Faisalabad, Pakistan. A non-irradiated sample, kept under the same storage conditions, was used as a control.

\subsection{Oil extraction}

The irradiated and non-irradiated almond seeds (var. Misson and Price) were crushed using an electric grinder and the oils were extracted with $n$-hexane using a Soxhlet extractor for 7-8 hours in a water bath. After extraction, the solvent was evaporated under vacuum in a rotary evaporator (N-N Series) coupled with an aspirator and a digital water bath SB-651 (Eyela, Rikakikai Co. Ltd., Tokyo, Japan) at $45{ }^{\circ} \mathrm{C}$ and the extracted oils were stored at $4{ }^{\circ} \mathrm{C}$ until further analyses (Wijeratne et al., 2006).

\subsection{Proximate seed parameters}

After oil extraction from the control and irradiated almond seeds, the residue was subjected to proximate analyses following the standard methods. Protein contents were determined using the Kjeldahl apparatus according to AOAC method (AOAC, 1990). The fiber content was estimated by taking $2 \mathrm{~g}$ of defatted ground residual sample. The samples were boiled with $250 \mathrm{~mL}$ of $0.25 \mathrm{M}$ $\mathrm{H}_{2} \mathrm{SO}_{4}$, followed by the filtration and washing of insoluble residues. The residues were then boiled with $250 \mathrm{~mL}$ of $0.313 \mathrm{M} \mathrm{NaOH}$, followed by separation, washing, and drying. The dried residues were weighed and ashed at $600{ }^{\circ} \mathrm{C}$ using a muffle furnace (Eyela, TMF-2100, Tokyo, Japan); the loss in mass was determined gravimetrically 
(AOAC, 1990). For determination of ash contents, $2 \mathrm{~g}$ residue, left after oil extraction, were carborized and ashed in a muffle furnace at $600{ }^{\circ} \mathrm{C}$ until a constant mass was reached (ISO, 1977).

\subsection{Physico-chemical characteristics of oils}

The physiocochemical parameters such as density, refractive index, iodine value, saponification value, acid value, peroxide value and unsaponifiable matter of the oils extracted form un-irradiated and irradiated almond seeds were measured by IUPAC methods (IUPAC, 1987).

\subsection{Oxidative status of oils}

The oxidative status of the oils extracted from non-irradiated and irradiated almond seeds was evaluated spectrophotometrically. The oil samples were diluted using iso-octane and the absorbance which corresponded to conjugated dienes and trienes was recorded at $\lambda_{\max } 232 \mathrm{~nm}$ and $\lambda_{\max } 268$ $\mathrm{nm}$, respectively. Using the absorbance data the extinction coefficients were calculated following the IUPAC method (1987). For the measurement of para-anisidine value, the oil samples were dissolved in iso-octane and made to react with 5 $\mathrm{mL}$ of a $P$-anisidine solution $(0.25 \% \mathrm{w} / \mathrm{v}$ in acetic acid) for 10 min (IUPAC, 1987). A colored complex was formed; its absorbance was measured at a wavelength of $350 \mathrm{~nm}$ using a double beam spectrophotometer (Cecil, 7200, UK).

\subsection{Fatty acid profile of oils}

The almond kernel oils were analyzed for fatty acid profiles according to the standard method (IUPAC, 1987). The oils extracted $(0.2 \mathrm{~g})$ were transmethylated with potassium methoxide by refluxing at $50{ }^{\circ} \mathrm{C}$ in a round bottom flask resulting in fatty acid methyl esters (FAMEs). After the transesterification, the mixture was cooled to room temperature and the contents transferred into a separating funnel. A small volume of $n$-hexane was added into the funnel and the mixture was shaken and then centrifuged for phase separation. The upper FAMEs layer was decanted,washed with distilled water and further dried with anhydrous sodium sulphate. Finally after filtration, the FAMEs recovered were ready for the gas chromatographic analysis. FAMEs were analysed on a SHIMADZU gas chromatograph model 17-A, fitted with an SP2330 (Supelco) methyl-lignocerate-coated (film thickness $0.20 \mu \mathrm{m})$ polar capillary column $(30 \mathrm{~m}$ $\times 0.32 \mathrm{~mm}$ ) and a flame ionizing detector (FID). Oxygen-free nitrogen was used as carrier gas at a flow rate of $3 \mathrm{~mL} / \mathrm{min}$. Other analytical conditions were as follow: initial oven temperature, $180^{\circ} \mathrm{C}$; ramp rate, $5^{\circ} \mathrm{C} \mathrm{min}^{-1}$; final temperature, $220^{\circ} \mathrm{C}$; injector temperature, $230^{\circ} \mathrm{C}$; detector temperature, $250{ }^{\circ} \mathrm{C}$. The FAMEs were identified by comparing their relative and absolute retention times with those of pure standards. The FA composition was reported as a relative percentage of the total peak area. Nonadecanoic acid was used as internal standard. All of the quantitative measurements were monitored using a Chromatography Station for Windows (CSW32) data handling software (Data APEX, Pague 5, The Czech Republic).

\subsection{Tocopherol contents of oils}

The tocopherol composition of almond oils (irradiated and non-irradiated) was studied using a high performance liquid chromatograph, model LC$10 \mathrm{~A}$ series coupled with a liquid pump LS 10AS, a system controller SCL-10A, a Supelco C18 column $(250 \times 4.6 \mathrm{~mm} ; 5 \mu \mathrm{m})$, a fluorescence detector RF-530 and an injector loop of 20- $\mu \mathrm{L}$ (Rheodyne, USA). The column was operated at $30^{\circ} \mathrm{C}$. A mobile phase consisting of a mixture of acetonitrile and methanol $(1: 1 \mathrm{v} / \mathrm{v})$ at a flow rate of $1.3 \mathrm{~mL}$ $\mathrm{min}^{-1}$ was used. A sample for the chromatographic analysis was prepared by dissolving $1 \mathrm{~g}$ of almond oil into $2 \mathrm{~mL}$ of freshly distilled 2-propanal in a $5 \mathrm{~mL}$ sample vial. Tocopherol isomers in the eluent were detected using a fluorescence detector set at an emission wavelength of $325 \mathrm{~nm}$ and an excitation of $295 \mathrm{~nm}$. Qualitative and quantitative measurements for the individual tocopherols were performed by comparing the retention time and area of the unknown with those of pure standards of $\alpha-, \gamma$, and $\delta$-tocopherols.

\subsection{Microbiological analysis of oils}

The oil, extracted from non-irradiated and irradiated almond seeds, to the absorbed doses of 2, 4, 6, 8 and $10 \mathrm{kGy}$, were analyzed for the total bacterial and total fungal count according to the method described by Arici et al., (2007). In each of the three replicate experiments, $1.0 \mathrm{~mL}$ oil sample was mixed with $10 \mathrm{~mL}$ of $2 \%$ autoclaved peptone water. The samples were diluted and plated on agars. Nutritional agar (DIFCO, USA) was used for bacterial counts and potato dextrose agar (Oxoid, UK), acidified with $10 \%$ tartaric acid, was used for yeast. Total bacterial counts were performed after incubation at $37^{\circ} \mathrm{C}$ for $24 \mathrm{hrs}$ and yeast colonies of the non-irradiated and irradiated oil samples were counted after 3 days of incubation at $28^{\circ} \mathrm{C}$. These microbial analyses were performed at the Bioassay Section, Protein Molecular Biology Lab., Department of Chemistry and Biochemistry, University of Agriculture, Faisalabad.

\subsection{Statistical analysis}

Almond seeds (irradiated \& unirradiated) were analyzed in triplicate and the results were reported as means \pm SD. Statistical significance of the difference between mean values was assessed by ANOVA Staistix 8.1 version (Steel et al., 1992). 


\section{RESULTS AND DISCUSSION}

The proximate composition (oil, fiber, moisture, ash and protein contents) of unirradiated and irradiated almond (var. Mission and Price) seeds is given in Table 1. The irradiation up to $10 \mathrm{kGy}$ did not show any significant $(p<0.05)$ effect on the proximate composition (oil, fiber, moisture, ash and protein contents) of almond (var. Mission and Price) seeds (Table 1). The contents of oil and protein of the unirradiated (control) and irradiated almond seeds, with contributions of 40.0-40.1,39.8$40.4 \%$ and $22.7-24.8,22.4-24.7 \%$, respectively did not vary significantly between the treated and untreated samples. Similarly, the levels of moisture (7.3-8.2\%), ash (4.2-4.8\%) and fiber (5.3-5.6\%) in the unirradiated seeds was comparable with those (7.3-8.3\%, $4.1-4.8 \%$ and $5.2-5.6 \%$ ) of the irradiated ones revealing no considerable vartaions between the two types.

Our results, related to the proximate analyses, are consistent with previous reports which also reveal non significant difference in moisture, fat, ash and protein contents between irradiated and unirradiated almond seeds (Al-Bachir, 2004). Similarly, Bela et al., (2008) also reported that the protein and crude fiber contents of almonds did not change after irradiation. In agreement with our present results, Bhatti et al., (2010) and Yaqoob et al., (2010) also determined that gamma irradiation (2-10 kGy) did not affect the lipids, protein, fiber and ash contents of either sunflower nor maize seeds significantly $(p<0.05)$.

The refractive index, density, iodine value, saponification value, unsaponifiable matter and free fatty acid contents determined for the oils produced from unirradiated and irradiated almond seeds, to the absorbed doses from 2-10 kGy, are given in Table 2. There was no difference for the values of refractive index and density between the irradiated (1.4600-1.4700, $\left.0.89-0.90 \mathrm{mg} \mathrm{mL}{ }^{-1}\right)$ and nonirradiated oil samples (1.4599-1.4700,0.90-0.91 mg/ $\mathrm{mL}$ ), respectively, indicating that $\gamma$-radiation up to doses of $10 \mathrm{kGy}$ did not exert a significant negative effect on these parameters of the oils. Our results are in accordance with the previously reported findings of Bhatti et al., (2010) and Yaqoob et al., (2010) who also did not observe any significant change in refractive indices and densities between the controls and irradiated peanut, sunflower and maize oils. The refractive index and density values depend on thermal degradation and percentage of polar compounds formed during oxidation and hydrolytic reactions (Benedito et al., 2007).

As a result of exposure to gamma radiation, the iodine values of the control almond oils (105.7-110.7 $\mathrm{g}$ of I $100 \mathrm{~g}^{-1}$ oil ) were found to be substantially decreased to the levels as low as 61.3-79.3 $\mathrm{g}$ of I $100 \mathrm{~g}^{-1}$ oil (the values for samples exposed to 10 kGy dose). Generally, at higher doses the decline in the oils' iodine value was more remarkeable. The decreasing trend in the oil iodine value upon irradiation in this study might refer to the saturation of the oil as a result of the breakdown of double bonds due to oxidative deterioration in the fatty acids. A similar decreasing trend in iodine value has already been seen (Al-Bachir, 2004; Anjum et al., 2006; Bhatti et al., 2010; Yaqoob et al., 2010). The oils saponification values increased upon irradiation (an increase from 185-187 to 204$231 \mathrm{mg} \mathrm{KOH} \mathrm{g}^{-1}$ of oil) which indicated that large original molecules of oils containing long-chain fatty acids degraded to smaller molecules as a result of oxidation and cleavage of bonds (Agatemor,

Table 1

Effect of gamma irradiation on proximate composition (\%) ${ }^{\mathrm{a}}$ of almond seeds of different varieties

\begin{tabular}{|c|c|c|c|c|c|c|c|}
\hline \multirow{2}{*}{ Contents } & \multirow{2}{*}{ Variety } & \multicolumn{6}{|c|}{ Radiation doses } \\
\hline & & Control & 2 kGy & 4 kGy & 6 kGy & 8 kGy & 10 kGy \\
\hline \multirow[t]{2}{*}{ Oil } & Mission & $40.0 \pm 1.5$ & $40.0 \pm 2.0$ & $39.8 \pm 1.0$ & $40.3 \pm 1.5$ & $40.4 \pm 1.0$ & $40.0 \pm 2.0$ \\
\hline & Price & $40.1 \pm 2.0$ & $40.0 \pm 1.8$ & $40.0 \pm 2.0$ & $39.8 \pm 1.4$ & $40.3 \pm 2.0$ & $39.9 \pm 1.7$ \\
\hline \multirow[t]{2}{*}{ Moisture } & Mission & $7.3 \pm 0.9$ & $7.3 \pm 0.5$ & $7.6 \pm 0.6$ & $7.6 \pm 0.8$ & $7.6 \pm 0.8$ & $7.8 \pm 0.7$ \\
\hline & Price & $8.2 \pm 0.5$ & $8.3 \pm 0.8$ & $8.2 \pm 1.0$ & $8.2 \pm 0.4$ & $8.2 \pm 0.8$ & $8.2 \pm 1.0$ \\
\hline \multirow[t]{2}{*}{ Protein } & Mission & $22.7 \pm 1.5$ & $22.5 \pm 1.0$ & $22.5 \pm 1.1$ & $22.4 \pm 1.0$ & $22.5 \pm 1.1$ & $22.7 \pm 1.1$ \\
\hline & Price & $24.8 \pm 0.9$ & $24.3 \pm 1.5$ & $24.3 \pm 1.2$ & $24.7 \pm 1.0$ & $24.7 \pm 1.7$ & $24.2 \pm 1.0$ \\
\hline \multirow[t]{2}{*}{ Fiber } & Mission & $5.6 \pm 0.3$ & $5.5 \pm 0.5$ & $5.6 \pm 0.3$ & $5.5 \pm 0.6$ & $5.5 \pm 0.8$ & $5.5 \pm 0.4$ \\
\hline & Price & $5.3 \pm 0.5$ & $5.2 \pm 0.4$ & $5.3 \pm 0.3$ & $5.3 \pm 0.5$ & $5.3 \pm 0.7$ & $5.3 \pm 0.9$ \\
\hline \multirow[t]{2}{*}{ Ash } & Mission & $4.2 \pm 0.6$ & $4.1 \pm 0.5$ & $4.4 \pm 0.5$ & $4.6 \pm 0.4$ & $4.6 \pm 0.8$ & $4.5 \pm 0.5$ \\
\hline & Price & $4.8 \pm 0.5$ & $4.8 \pm 0.5$ & $4.8 \pm 0.6$ & $4.8 \pm 0.6$ & $4.8 \pm 0.2$ & $4.8 \pm 0.7$ \\
\hline
\end{tabular}

Mean \pm SD calculated from three replicates.

${ }^{a}$ The mean values of oil, moisture, protein, fiber and ash within the same row are non-significantly $(P<0.05)$ varied among radiation doses.

Control (non-irradiated sample). 
Table 2

Effect of gamma irradiation on physico-chemical parameters of oils extracted from almond seeds of different varieties

\begin{tabular}{|c|c|c|c|c|c|c|c|}
\hline \multirow{2}{*}{ Parameters } & \multirow{2}{*}{ Variety } & \multicolumn{6}{|c|}{ Radiation doses } \\
\hline & & Control & 2 kGy & 4 kGy & 6 kGy & 8 kGy & $10 \mathrm{kGy}$ \\
\hline \multirow[t]{2}{*}{ Refractive index $\left(40^{\circ} \mathrm{C}\right)$} & Misson & $1.4700 \pm 0.002^{\mathrm{a}}$ & $1.4700 \pm 0.002^{\mathrm{a}}$ & $1.4600 \pm 0.003^{\mathrm{a}}$ & $1.4600 \pm 0.001^{\mathrm{a}}$ & $1.4700 \pm 0.004^{\mathrm{a}}$ & $1.4699 \pm 0.002^{a}$ \\
\hline & Price & $1.4600 \pm 0.002^{\mathrm{a}}$ & $1.4699 \pm 0.003^{\mathrm{a}}$ & $1.4600 \pm 0.002^{\mathrm{a}}$ & $1.4600 \pm 0.002^{\mathrm{a}}$ & $1.4599 \pm 0.002^{\mathrm{a}}$ & $1.4600 \pm 0.003^{\mathrm{a}}$ \\
\hline \multirow[t]{2}{*}{ Density $(\mathrm{mg} / \mathrm{mL})\left(25^{\circ} \mathrm{C}\right)$} & Misson & $0.89 \pm 0.04^{\mathrm{a}}$ & $0.90 \pm 0.05^{\mathrm{a}}$ & $0.90 \pm 0.05^{\mathrm{a}}$ & $0.90 \pm 0.04^{a}$ & $0.91 \pm 0.05^{\mathrm{a}}$ & $0.91 \pm 0.05^{\mathrm{a}}$ \\
\hline & Price & $0.91 \pm 0.05^{a}$ & $0.90 \pm 0.05^{a}$ & $0.91 \pm 0.05^{\mathrm{a}}$ & $0.91 \pm 0.05^{\mathrm{a}}$ & $0.91 \pm 0.05^{\mathrm{a}}$ & $0.90 \pm 0.05^{\mathrm{a}}$ \\
\hline \multirow[t]{2}{*}{ lodine value ( $\mathrm{g}$ of $\mathrm{l} / 100 \mathrm{~g}$ oil) } & Misson & $105.7 \pm 4.1^{a}$ & $101.7 \pm 4.3^{\mathrm{ab}}$ & $97.8 \pm 5.0^{\mathrm{abc}}$ & $94.0 \pm 4.7^{\mathrm{bc}}$ & $86.6 \pm 4.3^{\mathrm{cd}}$ & $79.3 \pm 3.7^{d}$ \\
\hline & Price & $110.7 \pm 4.0^{\mathrm{a}}$ & $101.8 \pm 3.0^{\mathrm{ab}}$ & $93.0 \pm 4.0^{\mathrm{abc}}$ & $86.6 \pm 4.3^{b c}$ & $74.0 \pm 3.7^{c d}$ & $61.3 \pm 3.0^{d}$ \\
\hline \multirow[t]{2}{*}{ Unsponifiabale matter (\%) } & Misson & $0.43 \pm 0.02^{\mathrm{a}}$ & $0.43 \pm 0.02^{a b}$ & $0.53 \pm 0.03^{\text {bc }}$ & $0.54 \pm 0.03^{\text {bc }}$ & $0.62 \pm 0.03^{c}$ & $0.76 \pm 0.04^{c}$ \\
\hline & Price & $0.38 \pm 0.02^{\mathrm{a}}$ & $0.38 \pm 0.02^{\mathrm{ab}}$ & $0.45 \pm 0.02^{b c}$ & $0.45 \pm 0.02^{b c}$ & $0.48 \pm 0.02^{c}$ & $0.52 \pm 0.03^{c}$ \\
\hline \multirow[t]{2}{*}{ Saponification value (mg KOH/g of oil) } & Misson & $185.0 \pm 4.5^{\mathrm{a}}$ & $190.0 \pm 3.5^{\mathrm{ab}}$ & $194.0 \pm 3.7^{7 \mathrm{acc}}$ & $197.0 \pm 2.9^{b c}$ & $201.0 \pm 4.0^{b c}$ & $204.0 \pm 3.5^{c}$ \\
\hline & Price & $187.0 \pm 3.5^{\mathrm{a}}$ & $188.7 \pm 4.4^{\mathrm{ab}}$ & $190.0 \pm 3.5^{\mathrm{abc}}$ & $208.0 \pm 4.5^{\mathrm{bc}}$ & $219.5 \pm 2.9^{b c}$ & $231.0 \pm 4.0^{c}$ \\
\hline \multirow[t]{2}{*}{ Free fatty acids (\% as oleic acid) } & Misson & $1.11 \pm 0.06^{\mathrm{a}}$ & $1.17 \pm 0.06^{\mathrm{a}}$ & $1.28 \pm 0.06^{\mathrm{ab}}$ & $1.28 \pm 0.10^{b c}$ & $1.34 \pm 0.07^{\mathrm{cd}}$ & $1.34 \pm 0.07^{d}$ \\
\hline & Price & $1.61 \pm 0.08^{a}$ & $1.64 \pm 0.08^{\mathrm{a}}$ & $1.67 \pm 0.08^{\mathrm{ab}}$ & $1.78 \pm 0.09^{b c}$ & $1.84 \pm 0.09^{c d}$ & $1.90 \pm 0.01^{d}$ \\
\hline
\end{tabular}

Mean \pm SD calculated from three replicates.

The means with different superscript letters within the same row vary significantly $(P<0.05)$ among radiation doses. Control (non-irradiated sample).

2006). Similarly, in the case of unsaponifiable matter, an increasing trend was observed with gamma radiation absorbed doses. These results are in accordance with Yaqoob et al., (2010) who reported an increase in unsaponifiable matter in sunflower and maize oil extracted form gamma irradiated seeds. In our experiments, the highest unsaponifiable matter $(0.52-0.76 \%)$ was observed for the samples irradiated to $10 \mathrm{kGy}$, which might be due to the existence of high contents of hydrocarbons, sterols and triterpenols at this stage (Uquiche et al., 2008). The increase in free fatty acids from $1.11-1.61 \%$ (for control oils) to $1.34-1.90 \%$ for oils extracted from $\gamma$-irradiated almond seeds, to a final dose of $10 \mathrm{kGy}$, might be due to slight and random hydrolysis of triglycerol molecules to free fatty acids and diacylglycerols (Al-Bachir, 2004; Boonchoo et al., 2005; Anjum et al., 2006; Badr, 2006).

The results regarding oxidative status of the oils produced from $\gamma$-irradiated and control almond seeds of both varieties are shown in Table 3. Irradiation significantly increased (an increase from 2.26-3.46 to $5.18-6.21$ meq $\mathrm{O}_{2} \mathrm{~kg}^{-1}$ oil) the peroxide value (PV) of the oils tested which might be attributed to the excessive formation of hydroperoxide as a result of oxidation, dehydration and polymerization reactions due to the interaction of $\gamma$ radiation with fat molecules (Evren and Gulden, 2008). Our results are in accordance with Badr, (2006) and Yusof et al., (2007) who also observed an increase in the peroxide values in gamma irradiated egg yolks and coconut oil samples. However, few previous reports are available where no significant increase upon irradiation was observed in the $\mathrm{PV}$ of different lipids (Hampson et al., 1996, Al-Bachir, 2004; Bhatti et al., 2010) which might be linked to the breakdown of primary oxidation products including hydroperoxide into smaller stable fragments such as carbonyl compounds, alcohols and hydrocarbons. Peroxide value characterizes the quantity of peroxides formed in the oils as intermediates of oxidative reactions after irradiation (Uquiche et al., 2008). Peroxide value characterizes the quantity of peroxides formed in the oils as intermediates of oxidative reactions after irradiation (Uquiche et al., 2008). The effect of $\gamma$ irradiation (up to $10 \mathrm{kGy}$ ) on the para-anisidine value (an increase from 20.10 to 23.50 ) in this study was found to be significant in accordance with the findings of Yaqoob et al., (2010). The extinction coefficients corresponding to $\lambda_{\max } 232 \mathrm{~nm}$ and $\lambda_{\max }$ 268 are related to the conjugated diene and trienes, respectively. The magnitude of these oxidation products is reflected as purity index and depicts the oxidative degradation of oil. These values were affected slightly at low radiation doses but increased rapidly at doses higher than $6 \mathrm{kGy}$. The oxidative stability of oils predicts their resistance to the formation of conjugated dienes, trienes and peroxides. Conjugated diene and triene values correspond to bond shifting as a result of oxidation (Deiana et al., 2002). The increase in the conjugated diene and triene contents for both varieties of almond seed oils observed in the present investigation might be linked to the lipid oxidation caused by irradiation (Bhatti et al., 2010).

Table 4 depicts the values of tocopherol homologues of the oils extracted from unirradiated 
Table 3

Effect of gamma irradiation on oxidative stability of oils extracted from almond seeds of different varieties

\begin{tabular}{|c|c|c|c|c|c|c|c|}
\hline \multirow{2}{*}{ Contents } & \multirow{2}{*}{ Variety } & \multicolumn{6}{|c|}{ Radiation dose } \\
\hline & & Control & 2 kGy & 4 kGy & 6 kGy & 8 kGy & 10 kGy \\
\hline \multirow[t]{2}{*}{$\varepsilon_{1 \mathrm{~cm}}{ }^{1 \%}(\lambda 232)$} & Misson & $1.91 \pm 0.10^{\mathrm{a}}$ & $2.09 \pm 0.10^{\mathrm{ab}}$ & $2.28 \pm 0.11^{b c}$ & $2.97 \pm 0.15^{\mathrm{cd}}$ & $3.45 \pm 0.17^{\mathrm{de}}$ & $3.93 \pm 0.20^{\mathrm{e}}$ \\
\hline & Price & $1.71 \pm 0.09^{\mathrm{a}}$ & $2.14 \pm 0.11^{\mathrm{ab}}$ & $2.53 \pm 0.13^{b c}$ & $2.80 \pm 0.14^{\mathrm{cd}}$ & $3.07 \pm 0.15^{\mathrm{de}}$ & $3.34 \pm 0.17^{e}$ \\
\hline \multirow[t]{2}{*}{$\varepsilon_{1 \mathrm{~cm}}{ }^{1 \%}(\lambda 268)$} & Misson & $0.22 \pm 0.01^{a}$ & $0.36 \pm 0.03^{\mathrm{ab}}$ & $0.49 \pm 0.02^{b}$ & $0.68 \pm 0.03^{c}$ & $0.73 \pm 0.04^{d}$ & $0.78 \pm 0.04^{e}$ \\
\hline & Price & $0.21 \pm 0.01^{\mathrm{a}}$ & $0.31 \pm 0.03^{\mathrm{ab}}$ & $0.45 \pm 0.02^{b}$ & $0.51 \pm 0.03^{c}$ & $0.61 \pm 0.03^{d}$ & $0.77 \pm 0.04^{\mathrm{e}}$ \\
\hline \multirow[t]{2}{*}{$\mathrm{PV}\left(\mathrm{meqO}_{2} \mathrm{~kg}^{-1}\right.$ of oil $)$} & Misson & $3.46 \pm 0.17^{\mathrm{a}}$ & $3.75 \pm 0.19^{b}$ & $4.03 \pm 0.20^{\circ}$ & $4.37 \pm 0.22^{d}$ & $5.29 \pm 0.26^{e}$ & $6.21 \pm 0.31^{\dagger}$ \\
\hline & Price & $2.26 \pm 0.15^{a}$ & $2.63 \pm 0.17^{b}$ & $3.00 \pm 0.20^{c}$ & $3.34 \pm 0.22^{d}$ & $4.26 \pm 0.30^{e}$ & $5.18 \pm 0.40^{f}$ \\
\hline \multirow[t]{2}{*}{ Para-anisidine Value } & Misson & $20.30 \pm 1.00^{\mathrm{a}}$ & $20.75 \pm 1.04^{a}$ & $21.20 \pm 0.99^{b}$ & $21.70 \pm 1.09^{b}$ & $22.60 \pm 1.30^{\circ}$ & $23.50 \pm 1.18^{d}$ \\
\hline & Price & $20.10 \pm 1.10^{a}$ & $20.55 \pm 1.03^{\mathrm{a}}$ & $21.00 \pm 1.00^{b}$ & $21.50 \pm 1.28^{b}$ & $22.40 \pm 1.12^{c}$ & $23.30 \pm 1.15^{d}$ \\
\hline
\end{tabular}

Mean \pm SD calculated from three replicates.

The means with different superscript letters within the same row vary significantly $(P<0.05)$ among radiation doses. Control (non-irradiated sample).

Table 4

Effect of gamma irradiation on tocopherols content of oils extracted from almond seeds of different varieties

\begin{tabular}{|c|c|c|c|c|c|c|c|}
\hline \multirow{2}{*}{ Tocopherols (mg/Kg) } & \multirow{2}{*}{ Variety } & \multicolumn{6}{|c|}{ Radiation doses } \\
\hline & & Control & 2 kGy & 4 kGy & 6 kGy & 8 kGy & 10 kGy \\
\hline \multirow[t]{2}{*}{$\alpha$-Tocopherol } & Mission & $436.0 \pm 13.1^{a}$ & $410.0 \pm 12.3^{\mathrm{ab}}$ & $390.0 \pm 11.7^{\mathrm{ab}}$ & $375.0 \pm 11.3^{\mathrm{ab}}$ & $340.4 \pm 10.2^{\mathrm{ab}}$ & $425.0 \pm 12.8^{b}$ \\
\hline & Price & $485.0 \pm 14.6^{a}$ & $452.0 \pm 13.2^{\mathrm{ab}}$ & $439.0 \pm 13.2^{\mathrm{ab}}$ & $416.0 \pm 12.5^{\mathrm{ab}}$ & $405.0 \pm 12.2^{\mathrm{ab}}$ & $385.0 \pm 11.6^{b}$ \\
\hline \multirow[t]{2}{*}{$\gamma$-Tocopherol } & Mission & $8.8 \pm 0.3^{a}$ & $7.8 \pm 0.2^{b}$ & $6.1 \pm 0.2^{c}$ & $6.0 \pm 0.2^{c}$ & $4.1 \pm 0.1^{d}$ & $3.0 \pm 0.1^{\mathrm{e}}$ \\
\hline & Price & $9.0 \pm 0.3^{\mathrm{a}}$ & $7.4 \pm 0.2^{b}$ & $6.3 \pm 0.2^{c}$ & $5.3 \pm 0.2^{c}$ & $4.1 \pm 0.1^{d}$ & $2.9 \pm 0.1^{\mathrm{e}}$ \\
\hline \multirow[t]{2}{*}{$\delta$-Tocopherol } & Mission & $2.3 \pm 0.1^{a}$ & $2.2 \pm 0.1^{b}$ & $2.1 \pm 0.1^{\mathrm{bc}}$ & $1.9 \pm 0.1^{\mathrm{c}}$ & $1.6 \pm 0.1^{d}$ & $1.3 \pm 0.1^{\mathrm{e}}$ \\
\hline & Price & $2.8 \pm 0.1^{a}$ & $2.4 \pm 0.1^{b}$ & $2.3 \pm 0.1^{\mathrm{bc}}$ & $2.1 \pm 0.1^{c}$ & $1.9 \pm 0.1^{d}$ & $1.5 \pm 0.1^{\mathrm{e}}$ \\
\hline \multirow[t]{2}{*}{ Total Tocopherol } & Mission & $447.1 \pm 13.4^{a}$ & $420.0 \pm 12.6^{b}$ & $398.2 \pm 11.9^{b}$ & $382.9 \pm 11.5^{\mathrm{c}}$ & $346.0 \pm 10.4^{d}$ & $429.3 \pm 12.9^{e}$ \\
\hline & Price & $496.8 \pm 14.9^{a}$ & $461.8 \pm 13.9^{b}$ & $447.5 \pm 13.4^{b}$ & $423.3 \pm 12.7^{c}$ & $411.0 \pm 12.3^{d}$ & $389.4 \pm 11.7^{\mathrm{e}}$ \\
\hline
\end{tabular}

Mean \pm SD calculated from three replicates.

The means with different superscript letters within the same row vary significantly $(\mathrm{P}<0.05)$ among radiation doses. Control (non-irradiated sample).

and $\gamma$-irradiated almond seeds to the absorbed doses of 2-10 kGy. There was a noticeable difference in tocopherol contents $(\alpha, \gamma$ and $\delta)$ of the oil samples derived from irradiated verses non-irradiated (control) seeds. The values of $\alpha$-tocopherol in unirradiated almond oils were predominant (436 $\mathrm{mg} \mathrm{kg}^{-1}$ and $485 \mathrm{mg} \mathrm{kg}^{-1}$ ) in Mission and Price variety, respectively). Alphatocopherol contents were higher in the case of the non-irradiated Price verity as compared to Mission. Meanwhile, $\gamma$ - and $\delta$-tocopherols were detected in small amounts with contributions of 8.81-8.95 mg $\mathrm{kg}^{-1}$ and $2.32-2.80 \mathrm{mg} \mathrm{kg}^{-1}$, respectively in both the varieties of almond oils. Overall, the tocopherol values were decreased by increasing the irradiation dose and the trend was in accordance with the studies of Bhatti et al. (2010) and Yaqoob et al., (2010) who studied a decreasing trend in the amounts of total tocopherols of irradiated sunflower, maize and peanut oil up to absorbed doses of $10 \mathrm{kGy}$. The decreasing trend in the tocopherol contents of irradiated oil samples might be linked to the degradation of these antioxidant componenets during irradiation. Furthermore, due to the thermal oxidation of the oil, the tocopherol values may also decrease (Yaqoob et al., 2010). The effect of gamma radiations on the tocopherol contents of the oils from both almond varieties was similar. Previous studies conducted by Lalas et al., (2007), Lakritz and Thayer (1994), and Lakritz et al., (1995) showed that there was a slight decrease in tocopherol contents of seed oils, fresh chicken breast muscle, and red meat, respectively with an increase in gamma radiation doses. While another study on cooked minced chicken showed that there was no considerable 
effect of irradiation on the tocopherol contents up to 4 kGy (Galvin et al., 1998). Furthermore, the concentration of tocopherols depends on genotype, cultivar traits as well as agroclimatic conditions of the harvest (Kodad et al., 2011). It is known that $\alpha$-tocopherol along with tocotrienols (Vitamin E) are important liposoluble metabolites and due to their strong anti-oxidative effects, they retard the oxidation of unsaturated fatty acids in foods and biological systems. The most active form of vitamin $E$ in vivo is $\alpha$-tocopherol, while $\gamma$-tocopherol is an active form of vitamin $\mathrm{E}$ in vitro (Gimeno et al., 2000; Uquiche et al., 2010). Suhaj et al., (2006) reported that antioxidant activity was influenced by radiation treatment which can be attributed to the degradation and peroxidation of unsaturated fatty acid in the oils (Hassanein et al., 2003). Lalas et al., (2007) also reported a decrease in the total tocopherol contents of sunflower and soybean oils after irradiation at higher doses, while no significant change for tocopherol concentration was observed at lower doses. Similar results have been reported earlier in case of irradiated peanut, sunflower and maize seeds oils (Bhatti et al., 2010; Yaqoob et al., 2010). The contents of $\alpha-, \gamma$ - and $\delta$-tocopherols were slightly affected in the oils extracted from peanut, sunflower and maize seeds irradiated up to 6 kGy, however, the effect was comparatively pronounced at higher dosages.

Radiation-induced changes in the fatty acid profile for Mission and Price varieties of almond seeds are shown in Table 5. The effect of $\gamma$ radiation (dose 2-10 kGy) on fatty acid composition was found to be almost insignificant for palmitic acid (16:0), the content of stearic acid (18:0) and oleic acid (18:1) increased, while the concentration of linoleic acid (18:2) decreased significantly $(p<0.05)$ by increasing the absorbed dose. The increasing trend for stearic acid (an increase from 2.18-2.37 to 2.88-3.00\%) and oleic acid (an increase from $69.51-70.00$ to $70.25-71.5 \%$ ) and decreasing trend of linoleic acid (a decrease from $22.0-22.10$ to $20.05-20.90 \%$ ) might be due to the preferential cleavage of double bonds. Radiation treatment caused the saturation of double bonds of linoleic acid which increased with the absorbed dose. Our findings are in agreement with Yaqoob et al., (2010) who reported that the effects of irradiation on the fatty acid composition of sunflower oil showed a significant $(p<0.05)$ change in the amounts of stearic, oleic and linoleic acids, while the concentration of palmitic acid was unaffected even at $10 \mathrm{kGy}$.

The effect of gamma irradiation on the microbial inactivation of oils extracted from irradiated and unirradiated seeds of both varieties of almond are shown in Table 6. The bacterial populations in nonirradiated oil samples were $4.30 \times 10^{3} \mathrm{CFU} / \mathrm{g}$ and $3.87 \times 10^{3} \mathrm{CFU} / \mathrm{g}$ while the fungal spores $3.87 \times 10^{2}$ $/ \mathrm{mL}$ and $3.87 \times 10^{2} \mathrm{~mL}^{-1}$ for Mission and Price varieties, respectively. After radiation treatment of 2 kGy the bacterial load was reduced to $3.91 \times 10^{2}$ CFU g ${ }^{-1}$ for Mission variety and $3.21 \times 10^{2} \mathrm{CFU} / \mathrm{g}$ (Price) and the fungal count levels were $3.45 \times 10^{1}$ spores $\mathrm{mL}^{-1}$ (Mission) and $2.84 \times 10^{1}$ spores $\mathrm{mL}^{-1}$ for Price variety. A significant reduction of microbes was observed at an absorbed dose of 4 kGy whereas at 6 kGy irradiation increasingly hampered the microbial growth and no population wentundetected. Similar results as observed in the present investigation were reported by Thomas et al. (2008), who studied colony formation in black tea irradiated up to $10 \mathrm{kGy}$ absorbed dose. Likewise, Alighourchi et al., (2008) reported a progressive decrease in the microbial load of pomegranate juice irradiated to $0.5-10 \mathrm{kGy}$.

\section{CONCLUSIONS}

The results of this study showed that gamma irradiation up to an absorbed dose of 6 kGy did

Table 5

Effect of gamma irradiation on the fatty acidS profile (g/100 $\mathrm{g}$ FA) of oils extracted from almond seeds of different varieties

\begin{tabular}{|c|c|c|c|c|c|c|c|}
\hline \multirow{2}{*}{$\begin{array}{c}\text { Contents } \\
(\%)\end{array}$} & \multirow{2}{*}{ Variety } & \multicolumn{6}{|c|}{ Radiation doses } \\
\hline & & Control & 2 kGy & 4 kGy & 6 kGy & 8 kGy & 10 kGy \\
\hline \multirow[t]{2}{*}{ Palmitic acid } & Mission & $6.10 \pm 0.24^{a}$ & $6.13 \pm 0.25^{a}$ & $6.14 \pm 0.25^{a}$ & $6.14 \pm 0.25^{a}$ & $6.15 \pm 0.25^{a}$ & $6.16 \pm 0.25^{a}$ \\
\hline & Price & $6.17 \pm 0.25^{\mathrm{a}}$ & $6.21 \pm 0.25^{\mathrm{a}}$ & $6.21 \pm 0.25^{a}$ & $6.27 \pm 0.25^{\mathrm{a}}$ & $6.35 \pm 0.25^{\mathrm{a}}$ & $6.37 \pm 0.29^{a}$ \\
\hline \multirow[t]{2}{*}{ Stearic acid } & Mission & $2.18 \pm 0.09^{\mathrm{a}}$ & $2.18 \pm 0.09^{b}$ & $2.12 \pm 0.08^{b}$ & $2.55 \pm 0.10^{c}$ & $2.60 \pm 0.10^{\circ}$ & $2.88 \pm 0.12^{c}$ \\
\hline & Price & $2.37 \pm 0.09^{\mathrm{a}}$ & $2.45 \pm 0.10^{b}$ & $2.61 \pm 0.10^{b}$ & $2.71 \pm 0.11^{c}$ & $2.79 \pm 0.11^{c}$ & $3.00 \pm 0.12^{c}$ \\
\hline \multirow[t]{2}{*}{ Oleic acid } & Mission & $69.51 \pm 2.78^{\mathrm{a}}$ & $69.7 \pm 2.79^{\mathrm{ab}}$ & $69.89 \pm 2.80^{b c}$ & $69.9 \pm 2.88^{c}$ & $70.10 \pm 2.80^{c d}$ & $70.25 \pm 2.81^{d}$ \\
\hline & Price & $70.00 \pm 2.83^{\mathrm{a}}$ & $70.68 \pm 2.83^{\mathrm{ab}}$ & $70.77 \pm 2.83^{\mathrm{bc}}$ & $70.95 \pm 2.84^{\mathrm{C}}$ & $71.20 \pm 2.85^{c d}$ & $71.5 \pm 2.86^{\mathrm{d}}$ \\
\hline \multirow[t]{2}{*}{ Linolieic acid } & Mission & $22.10 \pm 0.88^{\mathrm{a}}$ & $21.80 \pm 0.88^{\mathrm{a}}$ & $21.60 \pm 0.86^{a}$ & $21.40 \pm 0.86^{\mathrm{a}}$ & $21.00 \pm 0.84^{\mathrm{a}}$ & $20.90 \pm 0.84^{\mathrm{a}}$ \\
\hline & Price & $22.00 \pm 0.90^{\mathrm{a}}$ & $22.10 \pm 0.88^{\mathrm{a}}$ & $21.85 \pm 0.87^{\mathrm{a}}$ & $21.40 \pm 0.86^{\mathrm{a}}$ & $20.00 \pm 0.83^{\mathrm{a}}$ & $20.05 \pm 0.80^{a}$ \\
\hline
\end{tabular}

Mean \pm SD calculated from three replicates.

The means with different superscript letters within the same row vary significantly $(P<0.05)$ among radiation doses.

Control (non-irradiated sample). 
Table 6

Bacterial (CFU/g) and fungal (spores/mL) count of oils extracted from almond seeds of different varieties

\begin{tabular}{cccccc}
\hline \multirow{2}{*}{ Dose (kGy) } & \multicolumn{2}{c}{ Total bacterial count $($ CFU/g) } & & \multicolumn{2}{c}{ Total fungal count (spores/mL) } \\
\cline { 2 - 3 } \cline { 5 - 6 } & Mission & Price & & Mission & Price \\
\hline Control & $4.30 \times 10^{3}$ & $3.87 \times 10^{3}$ & & $3.87 \times 10^{2}$ & $3.87 \times 10^{2}$ \\
2 & $3.91 \times 10^{2}$ & $3.21 \times 10^{2}$ & & $3.45 \times 10^{1}$ & $2.84 \times 10^{1}$ \\
4 & $2.41 \times 10^{1}$ & $2.84 \times 10^{1}$ & & $<10$ & $<10$ \\
6 & $N D$ & ND & & ND & ND \\
8 & ND & ND & & ND & ND \\
10 & ND & ND & & ND & ND \\
\hline
\end{tabular}

Mean calculated from three replicates, ND (not detected).

Control (non-irradiated sample).

CFU: Colony-forming unit.

not significantly alter the routine physiochemical characteristics of the almond (Mission and Price verity) oils, while the microbial load was nullified completely at this treatment level. The fatty acid and tocopherol profiles as well as the oxidation status of the irradiated oils were negatively affected especially at higher irradiation doses (>6 kGy). It can be concluded that higher gamma irradiation doses might lead to the deterioration of some valuable components such as tocopherols and essential fatty acids in the oils. In order to preserve the almond seed oil from disinfection as well as from some other quality-oriented deteriorative effects, an appropriate gamma irradiation treatment should be sought.

\section{ACKNOWLEDGEMENTS}

The authors are grateful to the authorities of Nuclear Institute of Agriculture and Biology (NIAB), Faisalabd, Pakistan, for providing the Cs-137, gamma irradiator, facility.

\section{REFERENCES}

Azim AMN, Shireen EAH, Gammaa AMO. 2009. Effect of gamma irradiation on the physico-chemical characteristics of ground nut (Arachis hypogaea). Aust. J. Basic Appl. Sci. 3, 2856-2860.

Agatemor C. 2006. Studies of selected physicochemical properties of fluted pumpkin (Telfairia occidentalis Hook F) seed oil and tropical almond (Terminalia catappia L.) seed oil. Pak. J. Nutr. 5, 306-307.

Ahmad Z. 2010. The uses and properties of almond oil. Complementary Ther. Clin. Pract. 16, 10-12.

Al-Bachir M. 2004. Effect of gamma irradiation on fungal load, chemical and sensorycharacteristics of walnuts (Juglans regia L.). J. Stored Prod. Res. 40, 355-362.

Alighourchi H. Barzegar M. Abbasi S. 2008. Effect of gamma irradiation on the stability of anthocyanins and shelf-life of various pomegranate juices. Food Chem. 110, 1036-1040.

Anjum F, Anwar F, Jamil A, Iqbal M. 2006. Microwave roasting effects on the physico-chemical composition and oxidative stability of sunflower seed oil. J. Am. Oil Chem. Soc. 83, 777-784.
AOAC. 1990. Official methods of analysis of the Association of Official Analytical Chemists. $15^{\text {th }}$ Edn., Association of Analytical Chemists, Arlington, VA, USA, Method 954.01.

Arici M, Colak FA, Gecgel U. 2007. Effect of gamma radiation on microbiological and oil properties of black cumin (Nigella sativa L.). Grasas Aceites. 58, 339343.

Badr HM. 2006. Effect of gamma radiation and cold storage on chemical and organoleptic properties and microbiological status of liquid egg white and yolk. Food Chem. 97, 285-293.

Barros L, Barreira JCM., Grangeia C, Batista C, Cadavez VAP, Ferreira IC. 2011. Beef burger patties incorporated with Boletus edulis extracts: Lipid peroxidation inhibition effects. Eur. J. Lipid Sci. Technol. 113, 737-743.

Benedito J, Garcıa-Perez JV, Carmen DM, Mulet A 2007. Rapid evaluation of frying oil degradation using ultrasonic technology. Food Res. Int. 40, 406-414.

Bela PS, Egeaa I, Romojaroa F, Concepcio M, Madrid M. 2008. Sensorial and chemical quality of electron beam irradiated almonds (Prunus amygdalus). Lebensm-Wiss-Technol. 41, 442-449.

Bhatti IA, Ashraf S, Shahid M, Asi MR, Mehboob S. 2010. Quality index of oils extracted from gamma-irradiated peanuts (Arachis hypogaea L.) of the golden and bari varieties. Appl. Radiation. Isot. 68, 2197-2201.

Boonchoo T, Jitareerat $\mathrm{P}$, Photchanachai $\mathrm{S}$, Chinaphuti A. 2005. Effect of gamma irradiation on Aspergillus flavus and brown rice quality during storage. In: International Symposium "New Frontier of Irradiated Food and Non-Food Products", September 22-23, 2005, KMUTT, Bangkok, Thailand (http://www.kmutt. ac.th/symposium/poster/21.pdf ).

Braghini R, Pozzi CR, Aquino S, Rocha LO, Correa B. 2009. Effects of gamma radiation on the fungus Alternaria alternata in artificially inoculated cereal samples. Appl. Radiat. Isot. 67, 1622-1628.

Brewer MS. 2009. Irradiation effects on meat flavor: A review. Meat Sci. 81, 1-14.

Chen CY, Milbury PE, Lapsley K, Blumberg JB. 2005. Flavonoids from almond skins are bioavailable and act synergistically with vitamins $C$ and $E$ to enhance hamster and human LDL resistance to oxidation. $J$. Nutr. 135, 1366-1373.

Cordeiro V, Monteiro A. 2001. Almond growing in Trasos-Montes region (Portugal). Acta Hortic. 591, 161165.

da Trindade RA, Mancini-Filho J, Villavicencio ALCH, 2009. Effects of natural antioxidants on the lipid 
profile of electron beam-irradiated beef burgers. Eur. J. Lipid. Sci. Technol. 111, 1161-1168.

Deiana M, Rosa A, Cao CFQ, Pirisi FM, Bandino G, Dessı MA. 2002. Novel approach to study oxidative stability of extra virgin olive oils: importance of alphatocopherol concentration. J. Agric. Food Chem. 50, 4342-4346.

Ehlermann DAE. 2009. The RADURA-terminology and food irradiation. Food Control. 20, 526-528.

Esfahlan AJ, Jamei R, Esfahlan RJ. 2010. The importance of almond (Prunus amygdalus L.) and its by-products. Food Chem. 120, 349-360.

Evren G, Gulden O. 2008. The effect of food irradiation on quality of pine nut kernels. Rad. Phy. Chem. 77, 365-369.

Galvin K, Morissey PA, Buckley DJ. 1998. Effect of dietary a-tocopherol supplementation and gammairradiation on tocopherol retention and lipid oxidation in cooked minced chicken. Food Chem. 62, 185-190.

Gimeno E, Castellote AI, Lamuela-Raventos RM, Torre MC, Lopez-Sabater MC. 2000. Rapid determination of vitamin $E$ in vegetable oils by reversed-phase highperformance liquid chromatography. J. Chromatogr. A. 881, 251-254.

Graham JA, Panozzo JF, Lim PC, Brouwer JB. 2002. Effects of gamma irradiation on physical and chemical properties of chickpeas (Cicer arietinum). J. Sci. Food. Agric. 82, 1599-1605.

IUPAC. International Union of Pure and Applied Chemistry,1987. Standard Methods for the Analysis of Oils, Fats and Derivatives, 7th rev. enlarged edn., edited by C. Paquot and A. Hautfenne, Blackwell Scientific, London.

ISO. 1977. Oilseed Residues Determination of Total Ash, International Organization for Standardization (ISO), Geneva, Switzerland. Standard No. 749.

Hampson JW, Fox JB, Lakritz L. 1996. Thayer DW, effect of low dose gamma radiation on lipids in five different meats. Meat Sci. 42, 271-276.

Hassanein MM, El-Shami SM, Hassan El-Mallah M. 2003. Changes occurring in vegetable oils composition due to microwave heating. Grasas Aceites. 54, 343-349.

Jalili M, Jinap S, Noranizan A. 2010. Effect of gamma radiation on reduction of mycotoxins in black. Food Control. 21, 1388-1393.

Kodad O, Estopanan G, Juan T, Mamouni A, Socias I Company R. 2011. Tocopherol concentration in almond oil: Genetic variation and environmental effects under warm conditions. J. Agric. Food Chem. 59, 6137-6141.

Lakritz L, Thayer DW. 1994. Effect of gamma radiation of total tocopherols in fresh chicken breasts muscle. Meat Sci. 37, 439-448.

Lakritz L, Fox JB, Hampson J, Richardson R. 1995. Effect of gamma radiation on levels of a-tocopherol in red meats and turkey. Meat Sci. 41, 261-271.

Lalas S, Gortzi O, Tsaknis J, Sflomos K. 2007. Irradiation effect on oxidative condition and tocopherol content of vegetable oils. Int. J. Mol. Sci. 8, 533-540.

Martins M, Tenreiro R, Oliveira MM. 2003. Genetic relatedness of Portuguese almond cultivars assessed by RAPD and ISSR markers. Plant Cell Reports, 22, 71-78.
Mexis SF, Kontominas MG. 2009. Effect of $\gamma$-radiation on physiochemical and sensory properties of walnuts (Juglans regia L.). Eur. Food Res. Technol. 228, 823-831.

Milbury PE, Chen CY, Dolnikowski GG, Blumberg JB. 2006. Determination of flavonoids and phenolics and their distribution in almonds. J. Agric. Food Chem. 54, 5027-5033.

Moure A, Pazos M, Medina I, Dominguez H, Parajo JC. 2007. Antioxidant activity of extracts produced by solvent extraction of almond shells acid hydrolysates. Food Chem. 101, 193-201.

Muik B, Lendl B, Molina-Dıaz A, Ayora-Canada MJ. 2005. Direct monitoring of lipid oxidation in edible oils by fourier transform raman spectroscopy. Chem. Phy. Lipids. 134, 173-182.

Prakash A, Lim FT, Duong C, Caporaso F, Foley D. 2010. The effects of ionizing irradiation on Salmonella inoculated on almonds and changes in sensory properties. Rad. Phys. Chem. 79, 502-506.

Richardsa A, Wijesunderaa C, Salisbury P. 2005. Evaluation of oxidative stability of canola oils by headspace analysis. J. Am. Oil Chem. Soc. 82, 869-874.

Rohman A, Che Man YB, Ismail A, Hashim P. 2011. Monitoring the oxidative stability of virgin coconut oil during oven test using chemical indexes and FTIR spectroscopy. Int. Food. Res. J. 18, 303-310.

Siddhuraju P, Makkar HPS, Becker K. 2002. The effect of ionising radiation on anti nutritional factors and the nutritional value of plant materials with reference to human and animal food. Food Chem. 78, 187-205.

Song HP, Kim B, Yun H, Kim DH, Kim YJ, Jo C. 2009. Inactivation of 3-strain cocktail pathogens inoculated into Bajirak jeotkal, salted, seasoned, and fermented short-necked clam (Tapes pilippinarum), by gamma and electron beam irradiation. Food Control. 20, 580-584.

Steel RGD, Torrie JH. 1992. Prienciples and procedures of Statistics. $2^{\text {nd }}$ Ed., McGraw Hill Book Co. Inc., Singapore.

Suhaj M, Racova J, Polovka M, Brezova V. 2006. Effect of gamma-irradiation on antioxidant activity of black pepper (Piper nigrum L.). Food Chem. 97, 696-704.

Thomas J, Senthilkumar RS, Kumar RR, Mandal AKA, Muraleedharan N. 2008. Induction of gamma-irradiation for decontamination and to increase the storage stability of black teas. Food Chem. 106, 180-184.

Uquiche E, Jerez M, Ortız J. 2008. Effect of pretreatment with microwaves on mechanical extraction yield and quality of vegetable oil from Chilean hazelnuts (Gevuina avellana Mol). Innov. Food Sci. Emerging Technol. 9, 495-500.

Yaqoob N, ljaz AB, Farooq A, Muhammad RA. 2010. Oil quality characteristics of irradiated sunflower and maiz seed. Eur. J. Lipid Sci. Technol. 112, 488-495.

Yusof N, Ramli RAA, Ali F. 2007. Chemical, sensory and microbiological changes of gamma irradiated coconut cream powder. Radiat. Phys. Chem. 76, 1882-1884.

Wijeratne SSK, Abou-zaid MM, Shahidi F. 2006. Antioxidant polyphenols in almond and its coproducts. J. Agric. Food Chem. 54, 312-318.

Recibido: 5/7/12 Aceptado: 28/11/12 